\title{
ZUSGS
}

\section{Cruise Report for A1-00-SC Southern California Earthquake Hazards Project, Part A}

By Christina E. Gutmacher ${ }^{1}$, William R. Normark ${ }^{1}$, Stephanie L. Ross ${ }^{1}$, Brian D.

Edwards $^{1}$, Ray Sliter ${ }^{1}$, Patrick Hart ${ }^{1}$, Becky Cooper ${ }^{1}$, Jon Childs ${ }^{1}$, and, Jane A. Reid ${ }^{1}$

Open-File Report 00-516

2000

This report is preliminary and has not been reviewed for conformity with U.S.

Geological Survey editorial standards or with the North American Stratigraphic Code. Any use of trade, firm, or product names is for descriptive purposes only and does not imply endorsement by the U.S. Government.

\section{U.S. DEPARTMENT OF THE INTERIOR}

\section{U.S. GEOLOGICAL SURVEY}

${ }^{1}$ Menlo Park, California 


\section{INTRODUCTION}

A three-week cruise to obtain high-resolution boomer and multichannel seismic-reflection profiles supported two project activities of the USGS Coastal and Marine Geology (CMG) Program: (1) evaluating the earthquake and related geologic hazards posed by faults in the near offshore area of southern California and (2) determining the pathways through which sea-water is intruding into aquifers of Los Angeles County in the area of the Long Beach and Los Angeles harbors. The 2000 cruise, A1-00-SC, is the third major data-collection effort in support of the first objective (Normark et al., 1999a, b); one more cruise is planned for 2002. This report deals primarily with the shipboard operations related to the earthquake-hazard activity. The sea-water intrusion survey is confined to shallow water and the techniques used are somewhat different from that of the hazards survey (see Edwards et al., in preparation).

\section{Project objectives}

The Southern California Earthquake Hazards project activity is supported through the Coastal and Marine Geology Program of the Geologic Division and is a component of the Geologic Division's Science Strategy under Goal 1 --- Conduct Geologic Hazard Assessments for Mitigation Planning (Bohlen et al., 1998). The southern California urban areas, which form the most populated urban corridor along the U.S. Pacific margin, are among a few specifically designated for special emphasis under the Division's science strategy (Bohlen et al., 1998). The focus of the Southern California Earthquake Hazards project is to identify the landslide, earthquake, and tsunami hazards and related ground-deformation processes occurring in the offshore areas that have significant potential to impact the inhabitants of the southern California coastal region.

The primary objective of the project field activity is to help mitigate the earthquake hazards for the southern California region by improving our understanding of how deformation is distributed (spatially and temporally) in the offshore with respect to the onshore region. To meet this objective, we are investigating the distribution, character, and age (including evidence for recurrence of displacement) of deformation within the basins and along the shelf adjacent to the most highly populated areas (Fig. 1). The initial results from the field mapping under this project will be used to identify possible sites for deployment of acoustic geodetic instruments to monitor strain in the offshore region.

\section{Study area}

The priorities for the field-mapping program are keyed to those areas with the greatest potential for impact on the southern California populace. Cruises in 1997-1999 concentrated on offshore areas near the Los Angeles metropolitan area and reconnaissance lines south to San Diego. For the 2000 seismic-reflection cruise, the main work areas were designed to complete mapping of 1) the coastal strip between Pt. Dume, north of Los Angeles, and San Diego (especially 0-3 n. mi.), where much of the hazard appears to be associated with strike-slip or oblique-slip faults; and 2) the active faults within the Santa Monica, San Pedro, and San Diego Trough basins, where more extensive sedimentation has left a sufficient stratigraphic record to aid in dating the recent faulting (see Fig. 1). The final project cruise planned for 2002 will focus on the offshore extension of the fold and thrust belt of the Western Transverse Range into the Santa Barbara Channel, and the boundary in the Channel Islands region between the strike-slip dominated deformation of the inner California Borderland and the thrust and fold deformation of the Santa Barbara Channel.

Figure 2 shows a generalized depiction of faults in the southern California region (adapted from Greene and Kennedy, 1986). Further interpretation of the key structures of the inner California borderland are available from site-specific studies and regional tectonic syntheses (e.g., see Clarke et al., 1985; Ziony and Yerkes; 1985; Vedder et al., 1986; Vedder, 1987; Wallace, 1990; Legg, 1991; Crouch and Suppe; 1993, Klitgord and Brocher; 1996, Clarke and Kennedy, 1997; Dolan et al., 1997; Pinter et al., 1998; Bohannon and Geist, 1998; Normark and Piper, 1998; Marlow et al., 2000; and Rivero et al., 2000). A major goal of mapping under this project is to provide detailed geologic and geophysical information in GIS data bases that build on the earlier studies and use new data to precisely locate active faults, to map recent submarine 
landslide deposits (e.g., Bohannon and Gardner, 2001), and to identify potential fault and landslide tsunamigenic sources.

The planned trackline survey for the cruise A1-00-SC was intended to both fill in gaps in survey coverage resulting from equipment problems during cruise A1-98-SC (Normark et al., 1999a) and to extend existing profiles from their termination at the three-mile limit as far as possible toward the shore. The nature and extent of the data gaps are illustrated by the compilation of existing trackline data (Fig. 3). The distribution of survey time between priorities 1 and 2 as noted above was intended to complete, as a minimum, a grid at two-kilometer spacings from the shore out to 40-50 km (see Fig. 3B in Normark et al., 1999b). Figure 4 shows the tracklines for A1-00-SC; note the work was concentrated inside the three-mile limit, with additional profiles collected from offshore Long Beach and the area within 30 miles north of San Diego.

\section{OPERATIONS}

This section gives an overview of the restrictions on sound sources, and information about the vessel, personnel, key operational events during the cruise, and equipment used. See Table 1 for a list of personnel and Table 2 for a more complete listing of general cruise operational information.

\section{Restrictions on use of the acoustic sound sources}

During the surveys in 1998 and 1999 using the multichannel seismic-reflection and Huntec systems offshore southern California, the project contracted with Cascadia Research to provide personnel for observing and recording marine mammal sightings (Normark et al., 1999a, b); we did again in 2000. The mammal observers were to notify USGS personnel on watch to shut off the sound sources, other than echosounder, when marine mammals came within a specified radius of the source. The purpose was to observe restrictions resulting from the Marine Mammal Protection Act (MMPA; see below). The protocols for shutdown of the sound sources were established prior to sailing, and the decision to shutdown was vested solely with the marinemammal observers and was not subject to veto by the chief scientist. The preclusion zone is a function of the power of the source and mammal sighted. For example, in 1999 we used both air-gun and Huntec sound sources and shutdown was required when whales approached within the specified 250-m-radius preclusion zone around either source. However, the preclusion zone radius was only $100 \mathrm{~m}$ for odontocetes (e.g., dolphins) or pinnipeds (e.g., seals). In 2000 we used a lower-power minisparker sound source in addition to the boomer and were allowed an exclusion zone radius of $30 \mathrm{~m}$ for odontocetes and pinnipeds, and $250 \mathrm{~m}$ for all whales. In all 3 years the radius of the whale exclusion zone exceeded the ship length + tow distance of the sound source, so observers had to look forward, to the sides and aft.

Following is a brief recounting of the permit process. The procedures for acquiring necessary permits to conduct seismic-reflection surveys off California using small sound sources are described in full by Childs et al. (1999).

For the 2000 field operation, the National Marine Fisheries Service (NMFS), which is the agency empowered to enforce the MMPA, again required that the U.S. Geological Survey apply for an Incidental Harassment Authorization (IHA). The IHA request process nominally takes 120 days and the request was submitted to NMFS in mid-January 2000. One part of the IHA process requires NMFS to make the application available for public comment, which is done through notification in the Federal Register.

In addition, the California Coastal Commission (CCC), under authorization granted by provisions of the Coastal Zone Management Act, required the USGS to submit a 'consistency determination,' which documents that a federal activity (in this case the geophysical survey) will be conducted (1) in a manner consistent with the state's coastal-zone management program and (2) in such a way that there will be no effect on coastal zone resources. The process of application to the CCC included discussion and review at a monthly meeting of the CCC, and for the 2000 cruise, the hearing was in early April. On 12 April, the USGS received unanimous approval from the CCC for operations as specified in the IHA permit application provided that the USGS agreed to modify its application such that the same preclusion area for marine mammals (30-m radius) be used for both shallow and deep water operations. 
After responding to questions from other parties (in addition to the CCC) raised as a result of the public comment period, there were followup discussions between the USGS and NMFS, and the USGS received the IHA permit on 5 June 2000. The IHA specified, among other restrictions, that:

(1) the USGS would have a minimum of three properly trained mammal observers approved in advance by NMFS;

(2) there would be a minimum of two mammal observers on watch during any period when any seismic sound source was being used; this requirement meant that the USGS had to provide a total of five marine mammal observers on the vessel to cover 24 hours of operation per day;

(3) the observers would record and report to NMFS "the estimated number of marine mammals (by species) that may have been harassed as a result of the seismic sources through noted behavioral change" and "any behavioral responses or modifications of these behavioral indicators due either to the seismic-reflection sources or to the vessel's noise";

(4) the protocol for shutdown of the minisparker sound source would be $30 \mathrm{~m}$ for dolphins, seals, and sea lions and $250 \mathrm{~m}$ for whales;

(5) at "all times, but specifically during nighttime surveys, the [ship's]crew must be instructed to keep watch for marine mammals [and that] if any are sighted, the watch-stander must immediately notify one of the biological observers;"

(6) "observations ......... on marine mammal presence and activity will begin a minimum of 30 minutes prior to the time that the seismic source will be turned on...." ; and

(7) the results of the monitoring will be reported to the Southwest Region, NMFS, and the Office of Protected Resources within 160 days from the end of the geophysical survey cruise.

Other restrictions included: in the event of observation of whales during daylight hours in shallow-water areas where nighttime surveying was planned, then surveying in water depths of less than $50 \mathrm{~m}$ was precluded. Although operating in deeper water was permitted, the vessel had to transit to the deeper water area with a minimum of 30 minutes of daylight to allow the observers to note if whales were present.

The program cost for meeting the requirements of the IHA are three fold: (1) the number of pay periods of CMG personnel required for the permitting process, which lasted from midDecember to early June, (2) the loss of seismic-reflection data collection during 41 shutdowns plus 2 transits to deeper water triggered by whale sightings by the marine mammal observers, and (3) the costs of the contract for the marine mammal observers and production of the required report for NMFS.

In addition to the restrictions on the survey resulting from the oversight responsibilities of the NMFS and CCC, the California State Lands Commission (SLC) has regulatory authority over waters within three miles of the coast. At the present time, the SLC prohibits all compressed-air seismic sound-sources (specifically air guns and water guns) regardless of size and regardless of the intended use, e.g., scientific research to define earthquake hazards is not sufficient to obtain an exemption to the ban. As a result, previous surveys with air-gun sources could not approach within three miles of the coast (e.g., note the data gap along the coast depicted in the trackline map of Fig. 3). The SLC also has restrictions on power of non air-gun sources such as sparker and boomer systems, but does allow small ones within the three-mile limit. As a result, the 2000 survey attempted to use a minisparker source of $<2 \mathrm{~kJ}$ for the multichannel seismic-reflection work.

All communication between the mammal team and the geophysical watchstanders was by radio. All conditions stated in the protocol were followed throughout the cruise. Appendix 1 is the report provided by Cascadia Research detailing the recordings of the marine-mammal observers as required by the IHA.

\section{Research platform}

The FY 2000 field program was conducted using a leased vessel, the 176-ft-long $M / V$ Auriga, owned and operated by F/V North Wind, Inc. The M/V Auriga, which was initially designed as an offshore oilfield supply vessel, is currently outfitted as an Alaskan crab-fishing boat. There are no laboratory compartments on the $M N$ Auriga, but the large open fantail area is amenable to installation of standard container shipping vans, each of which was outfitted for specific scientific function (Fig. 5). 
For the cruise A1-00-SC, three of the four vans installed on the M/V Auriga were the mainstay of the survey activities: (1) an electronics lab/underway-watch van for operating the navigation system and primary geophysical instruments, (2) a mechanical shop used for maintaining the tow sleds for the seismic-reflection sound sources, the winches and davits used for launch and recovery of both the boomer systems, and the streamer and sound source for the high-resolution reflection profiling system; and (3) an office van that also contained power supply systems for the acoustic sound sources. In addition to the science vans, a smaller van that was outfitted as quarters for two of the scientific party was placed on the after side of the 01 deck. Figure 5 shows the layout of science vans and equipment on the work deck of the vessel. The four vans and all associated deck equipment, including winches and davits, were loaded during a two-day mobilization period at Redwood City, CA.

\section{Scientific Party}

The scientific party for A1-00-SC included three scientists from the Southern California Earthquake Hazards project, five geophysical watchstanders, and six technical-support personnel from the Western Region CMG Marine Facilities staff (Table 1). In addition, there were seven contract personnel, one to oversee operation of the deep-tow boomer, one to effect repairs to the minisparker sound source, and five to provide a two-person, 24-hour watch for marine mammals whenever the seismic-reflection systems were in use. Personnel transfers on the $7^{\text {th }}$, $20^{\text {th }}, 23^{\text {rd }}$, and $25^{\text {th }}$ of June maintained the total scientific staff on the vessel at no more than 16 at any time.

\section{General Operations}

The geophysical survey was set for 7 to 27 June, 2000, departing and returning to the port of Redwood City, California, on 5 and 29 June, respectively. The ship departed in mid-morning on 5 June 2000 (Table 2). Following the 34-hour transit to the western boundary of the work area, the ship arrived at Port Hueneme for repairs to the vessel's gyro compass. Following repairs and the first exchange of scientific personnel, the ship departed Port Hueneme to rendezvous with a small boat, Blue Skies, from which Greenridge Associates conducted measurements of acoustic sound-source parameters for the seismic-reflection systems to be used during the surveys. The acoustic measurements were conducted early on 7 June, and by mid-afternoon were completed. At that time, the seismic-reflection systems were deployed to begin the planned survey. The geophysical survey took place between late on the $7^{\text {th }}$ to mid-day on the $27^{\text {th }}$ of June, 2000, including the work in and around the ports of Long Beach and Los Angeles that is reported elsewhere (Edwards et al., in preparation).

The general plan for survey lines during the cruise and the final survey tracklines (Fig. 4) differ considerably. There was significant loss of survey time as a result of equipment malfunctions. Specifically, the problems with the power supplies for the minisparker sound-source for the multichannel system resulted in multiple breaks in tracklines lines for testing. In addition, the minisparker could not be operated simultaneously with the boomer sound sources (either the Geopulse or Huntec) because of interference resulting from similar range of frequencies generated by the sources. This resulted in only one type of data, rather than both, being collected along each trackline. Table 2 shows the milestones for the main operational activities and primarily shows those events that affected the collection of data; the table includes annotations for equipment failures and maintenance periods, personnel transfer periods, and interruptions in the collection of seismic-reflection data as a result of encounters with marine mammals.

\section{Equipment Review}

A brief description of the survey equipment used during the cruise is given below. For specific times of data collection for the different systems used during the survey, navigate from this website:

http://walrus.wr.usgs.gov/docs/infobank/lion/a/a100sc/html/a-1-00-sc.meta.html 
Shipboard positioning system

Position data were collected with the USGS-designed YoNav Navigation system (Gann, 1992), with input from a CSI MBX3 GPS receiver operating in differential mode. The YoNav system is a PC-based data-acquisition and display program written in Microsoft $\mathrm{C} / \mathrm{C}++$ designed to provide navigation services on Windows NT platforms. The YoNav system incorporates a real-time trackline display and line-generating software for both the vessel's bridge watch and the scientific personnel. The display shows the ship's position relative to the desired survey line; enabling the bridge watch to keep the vessel within defined line parameters. An added advantage of the YoNav system is that the display could also be set to show one or more reference-data layers including bathymetric contours, shaded-relief images from multibeamsounding data, tracklines of previous surveys, and compilations of seafloor structural features.

Overall the YoNav system worked well, using GPS input to provide position data every ten seconds for $24 \mathrm{hrs} /$ day. Differential GPS positioning provides navigational accuracy of approximately $5 \mathrm{~m}$. Minimal problems with the shore-based reference stations were encountered during the survey; periods without differential GPS were limited to a few minutes, resulting in the occasional inaccurate fix that was off by several degrees of longitude, suggesting both bad data input and failure of YoNav to filter out bad data.

The most vexing problem involved shipboard post-processing of the navigation data. The YoNav system was unable to assign the correct UTM zone to position data collected during previous survey days. This, plus the lack of space to plot fixes by hand, made it very difficult to compare completed survey lines with either current or planned tracklines while at sea. A fix for this problem was prepared and delivered to the vessel during an unscheduled, mid-cruise port call at Scripps Institution of Oceanography (San Diego) to pick up a new power supply for the minisparker. The correction worked well, but needs further testing to ensure that it will work in UTM zones outside the southern California survey area as well as during future project surveys when tracklines will cross UTM zone boundaries. 
Multichannel seismic-reflection system

The sound source for multichannel seismic-reflection (MCS) profiling during the cruise was a 1.5 kJoule (kJ) "SQUID 2000" minisparker system manufactured by Applied Acoustic Engineering, Inc. This minisparker consists of eight sets of discharge electrodes, in two banks, mounted on a small pontoon sled (Fig. 5D). The pontoon sled that supports the minisparker is towed on the sea surface, generally about 5 meters behind the ship. The position of the tow cable for the minisparker sled is shown in Figure 5A. A total of approximately $85 \mathrm{~km}$ of minisparker data were collected with the MCS system and $15 \mathrm{~km}$ with the single-channel streamer alone, not including the 370-km survey, during Leg 2, in support of the aquifer study reported elsewhere (Edwards et al., in preparation).

Source characteristics of the SQUID $2000^{\mathrm{TM}}$ provided by the manufacturer show a soundpressure level (SPL) of $209 \mathrm{~dB}$ re $1 \mu \mathrm{Pa}-\mathrm{m}$ RMS. The amplitude spectrum of this pulse indicates that most of the sound energy lies between $150 \mathrm{~Hz}$ and $1700 \mathrm{~Hz}$, and the peak amplitude is at $900 \mathrm{~Hz}$. The output sound pulse of the minisparker has a duration of about 0.8 ms. For the multichannel seismic-reflection survey, the minisparker was discharged every 2 seconds, and when used with a single-channel streamer, at $400 \mathrm{~J}$, the fire rate varied from 300$750 \mathrm{~ms}$, depending on water depth.

The streamer for the MCS operation was a 24-channel solid-core ITI streamer with 10-m-long groups and 3 hydrophones per group. Data were collected using a Geometrics STRATAVIEW seismograph. Shots were triggered by an in-house controller. Data were recorded in SEG-D format on 4-gbyte DAT tapes using a $0.125 \mathrm{msec}$ sample rate and a record length that varied from 0.75 to 1.5 seconds. A $70-\mathrm{Hz}$ low-cut filter was used; otherwise all frequency bands were passed.

A 5-m-long SIG streamer with 8 hydrophones at 0.5-m spacing was also used for all minisparker lines. Data were collected using Triton-Elics International 'Delph Seismic' software. Data were recorded in SEG-Y format on the Delph system hard disc using sample frequencies between $250 \mathrm{~Hz}$ and $49 \mathrm{kHz}$, (usually $16 \mathrm{kHz}$ ) and up to 1 second record length. The data were recorded raw, e.g., without using bandpass filters or gain algorithms, and then backed up on CDROM during the cruise. The single channel minisparker data were also displayed in real time on thermal film using an EPC 9802 recorder.

The minisparker source did not function properly during most of the cruise. The primary problem involved the $1 \mathrm{~kJ}$ power-supply units, which repeatedly failed catastrophically after a relatively few minutes to several hours of operation (Table 2). About midway through the cruise, a new 2-kJ power supply provided by Applied Acoustic Engineering, Inc. was shipped to San Diego. Problems persisted, however, and near the end of the cruise, an engineer from the company flew to Los Angeles and boarded the vessel on the $22^{\text {nd }}$ of June. Even with the engineer's assistance, the $1 \mathrm{~kJ}$ power supplies continued to fail during the remainder of the cruise, except when used singly at low power (400-700 J). During the last three days of the survey, the new minisparker power supply provided fairly stable firing of one bank of 4 electrodes at $1.5 \mathrm{~kJ}$.

During the cruise, attempts to operate the multichannel system and the Huntec boomer system together proved unsatisfactory. Asynchronous firing of the boomer system in the time interval between the end of the recording window for the multichannel data and the succeeding trigger was unsatisfactory, especially in deeper water, as a result of the required uneven spacing of shots on the Huntec that produced gaps in the data. Simultaneous triggering of the multichannel and the Huntec system was likewise unsuccessful because the frequency ranges generated by the sound sources are similar enough to cause extensive cross-talk and resulting degradation of both minisparker and boomer data. 
Huntec

A high-resolution Huntec DTS (Deep-Towed Seismic) boomer system (Fig. 5F) towed between $20 \mathrm{~m}$ and $137 \mathrm{~m}$ below the sea surface (depending upon the water depth) was used to image the upper few tens of milliseconds of strata with a resolution of better than $0.5 \mathrm{~ms}(0.4$ $\mathrm{m})$. The Huntec system was operated primarily in areas of deeper water $(>300 \mathrm{~m})$ throughout the cruise. About $1400 \mathrm{~km}$ of Huntec survey data were obtained during the cruise, of which 1300 $\mathrm{km}$ were in support of the seismic hazards work.

The SPL for this source is $205 \mathrm{~dB}$ re $1 \mu \mathrm{Pa}-\mathrm{m}$ RMS. Power output was 375 Joules, with a firing rate that was also dependent on water depth, ranging from $0.5 \mathrm{sec}$ over the shelf and upper basin slopes to $1.67 \mathrm{sec}$ over the deeper parts of the basins. Returning signals were received

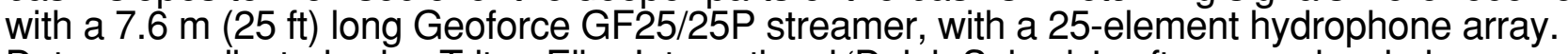
Data were collected using Triton-Elics International 'Delph Seismic' software and an in-house controller for triggering. Data were recorded in SEG-Y format on the Delph system hard disc using sample frequencies between $250 \mathrm{~Hz}$ and $49 \mathrm{kHz}$, (usually $16 \mathrm{kHz}$ ) and a 200 to 300 millisecond record length. The data were recorded raw, e.g., without using bandpass filters or gain algorithms. The data were then backed up on CD-ROM during the cruise. The Huntec data were also filtered at $640-4000 \mathrm{~Hz}$ and displayed in real time on thermal film using an EPC 9802 recorder. The average survey speed of about $4 \mathrm{kt}(7.4 \mathrm{~km} / \mathrm{hr})$ resulted in a shot spacing between 1.0 and $3.4 \mathrm{~m}$ for the deep-tow boomer profiles. The position of the tow cable for the Huntec vehicle is shown in Figure 5A.

The data quality provided by the Huntec system is excellent, and appeared comparable to the 1998 results (Normark et al., 1999a). The only shutdowns were for mammal sightings (Table 2).

\section{Geopulse}

The surface-towed Geopulse boomer system was used in the shallow water parts of the survey area, typically in water depths from $20 \mathrm{~m}$ to $300 \mathrm{~m}$ (Fig. 4). The sound source consists of two ORE Geopulse 5813A boomer plates mounted on a catamaran sled built in-house (Fig. 5C). The catamaran was towed from the same deck area as the multichannel sound source, while the short hydrophone streamer was towed from a boom on the starboard side of the vessel (Fig. 5A). About $1200 \mathrm{~km}$ of Geopulse data were obtained during the cruise, of which some $960 \mathrm{~km}$ were collected for the seismic hazards study.

The source level suggested by the manufacturer is $220 \mathrm{~dB}$ re $1 \mu \mathrm{Pa}-\mathrm{m}$ RMS. Power input was 350 Joules, with a firing rate that was also dependent on water depth: 0.5 or 1.0 second for the geologic hazard part of the survey and 0.25 second in the harbor areas. Returning signals were received with a 5-meter-long SIG streamer, with eight hydrophones at $0.5 \mathrm{~m}$ spacing. The effective bandwidth of the Geopulse system is about 750 to $3500 \mathrm{~Hz}$. The data were displayed in real time on thermal film using the same EPC 9802 recorder that was used for the Huntec data. As with the Huntec system, data were also recorded using the Triton-Elics International 'Delph Seismic' software in SEG-Y format generally using $16 \mathrm{~Hz}$ sample frequency and a 200 to 300 millisecond record length. The data were recorded raw, e.g., without using bandpass filters or gain algorithms, and were then backed up to CD-ROM during the cruise. The survey speed of 4 to $5 \mathrm{kt}(7.4$ to $9.2 \mathrm{~km} / \mathrm{hr})$ and the variable firing rate resulted in shot spacings generally between 1.0 and $2.5 \mathrm{~m}$ for the hazard profiles and $0.5 \mathrm{~m}$ spacing for the work in the Long Beach shelf and harbor areas (Edwards et al., in preparation).

The Geopulse system was trouble-free, except for its ability to capture kelp. 
Bathymetry $(12 \mathrm{kHz})$

A Knudsen Engineering, Ltd. 320 BR towed 12-kHz echosounder system was installed on the $M / V$ Auriga to provide a continuous water-depth profile primarily to ensure proper tow depth for the Huntec system. The position of the davit for towing the 12-kHz fish, which maintained a depth of 5 or $10 \mathrm{~m}$, is shown in Figure 5A. During transects across the basin slopes, when the water depth would change rapidly, the Huntec recording system required frequent time-delay (scale) changes. An independent measure of the water depth was desirable to avoid using the Huntec as a seafloor-sampling instrument.

Digitized data were logged on the YoNav system, and the bathymetric profiles displayed on a Raytheon TDU 850 recorder. The echo-sounding system performed without interruption in data collection except over steep terrain when the automatic tracking gate lost the signal returning from the seafloor, and during inspection of the tow vehicle, primarily to remove kelp snagged by the tow cable (Fig. 5E; Table 2). Regular observations of the 12-kHz display monitor suggests that there were few problems with the digital depth data.

\section{OVERVIEW OF SEISMIC-REFLECTION DATA}

This section briefly reviews the quality of the seismic-reflection data collected on A1-00-SC. Profile locations for Figures 7-12 are shown in Figure 6. Huntec and Geopulse profiles are compared in Figures 7 to 10. The selected examples of multichannel seismic-reflection profiles illustrate the effectiveness of the minisparker sound source when it was functioning normally (Fig. 11 and 12).

The Huntec data contain an acoustic artifact, the sea-surface ghost, resulting from reflection of the outgoing pulse by the sea surface. This sea-surface ghost looks like a subbottom profile that mimics the seafloor shape and swamps real data. It is especially a problem in shallow water where, if the Huntec is towed at $20 \mathrm{~m}$ depth for example, the ghost shows up in the data $20 \mathrm{~m}$ below the seafloor return. In deep water the Huntec is towed deeper, and that pushes the appearance of the sea-surface ghost below most real subbottom returns. For that reason the Huntec is used primarily in water deeper than $300 \mathrm{~m}$. The Geopulse often has superior results in water shallower than $300 \mathrm{~m}$, but loses effectiveness in deeper water.

The segments of high-resolution boomer profiles in Figures 7 and 8 compare data obtained during separate passes along the same test line near the edge of the shelf south of Long Beach, California (Fig. 6). In these examples, both the advantages and disadvantages of the Huntec and Geopulse systems are well illustrated. In shallow water on the shelf, both systems have a pronounced seafloor multiple (seen in the lower left-hand corner of Fig. 7A and B and the lower right-hand corner of Fig. 8A and B) that generally obscures deeper horizons. The Huntec system, which along this line was towed about $20 \mathrm{~m}$ below the sea surface, has a prominent seasurface ghost which blocks out deeper reflections from the primary pulse (Fig. 7B and 8B). The Geopulse system is better for shallow water applications even though it lacks the resolution of reflectors compared to the Huntec (compare reflections in areas labeled 'D' in Fig. 7A, B and 8A, B). In shallow water acoustic penetration on both systems tends to be limited by the seafloor multiple.

As noted above, the trade-off in data quality between using the two boomer-source systems is at about $300 \mathrm{~m}$ water depth. This trade-off is well illustrated in Figure 9, which compares data from subparallel tracklines that show the transition from basin slope to basin floor at about $300 \mathrm{~m}$ water depth. The two profiles cross near the edge of a turbidite channel on the basin floor (see Fig. 6 for location). Neither system obtained stellar data from the slope area, but there are marked differences over the basin floor. The vertical movement of the Geopulse catamaran in the ocean swells results in a wavy seafloor return and a loss of resolution of the closely spaced reflections in the overbank areas adjacent to the channel. The Huntec system shows a high degree of detail in the overbank sequences (compare areas labeled 'D' in Fig. 9A, B). In deeper water such as along this profile, the Huntec is towed at a greater depth, which not only reduces interference by the seasurface ghost, the longer tow length creates a catenary in the cable that helps damp out any vertical motion of the ship.

Although the Huntec boomer system is rarely towed deeper than $140 \mathrm{~m}$, excellent subbottom penetration can be achieved in the deeper basin areas. Figures 10A and 10B show two examples obtained from the Gulf of Santa Catalina (Fig. 6) in more than $800 \mathrm{~m}$ water depth. Both 
profile examples show about $100 \mathrm{~m}$ of acoustic penetration and in both cases the penetration is limited by the sea-surface ghost. The sea-surface ghost does not exactly mimic the seafloor shape in these profile segments indicating changes in the length of the tow cable to adjust the depth of the Huntec vehicle. The resolution obtained with the Huntec system shows progressive deformation of deeper reflectors caused by growth faults that do not show much relief at the seafloor. Much of the deformation observed below 850 m in Figure 10B is masked near the seafloor surface by recent turbidite sedimentation.

As noted earlier, the minisparker source for the multichannel system did not work much of the time. The multichannel lines shown in Figures 11 and 12 are from the northern slope of the Santa Monica Basin near Point Dume (Fig. 6). In Figure 11, the acoustic penetration is limited to about $0.4 \mathrm{sec}(\sim 300 \mathrm{~m})$ over the basin floor but with good resolution within the turbidite sequence. This profile can be correlated with the core recovered at ODP Site 1015 thus providing some age control on the fold developed at the base of the slope (Normark and Piper, 1998; Piper et al., 1999). The profile in Figure 12 extends to the shelf edge and is more typical of the lesser quality of data obtained with the minisparker system when it was working. There are no tracklines on which to directly compare the Huntec and multichannel minisparker data quality. However, in areas of similar water depth and subbottom type, the minisparker resolved about $300 \mathrm{~m}$ subbottom, while the Huntec resolved about $100 \mathrm{~m}$.

\section{SUMMARY}

As shown in the examples discussed above, the Geopulse and Huntec boomer-source seismic-reflection systems deployed for the 2000 earthquake-hazard survey generally provided satisfactory information for defining structures in the upper $50 \mathrm{~m}$ to $100 \mathrm{~m}$ within the seafloor sediment and sedimentary rock. In general, the Geopulse system was preferred for work in water depths less than $300 \mathrm{~m}$. Because the multichannel system did not function properly during the first two weeks of the survey, the operation focused on working inside the state three-mile limit, which had been off limits in the 1998 and 1999 surveys when air gun sources were used for the multichannel work. Operations in deeper water with the Huntec system were limited to filling in the gaps in earlier surveys, especially in the area between Dana Point and La Jolla.

Even with the survey generally limited to the boomer systems, the specified 30-m preclusion zone for marine mammals was applied. During the operation, 41 shutdowns were called, and two major transits to deep water after whale sightings near dusk, resulting in a total loss of survey time of about one-half day (11 hr, $6 \mathrm{~min})$.

\section{ACKNOWLEDGEMENTS}

We thank the captains and crew of the Auriga for their tremendous support of our cruise, from mobilization through demobilization. We are in debt to our own Marine Facility personnel who transformed the Auriga from crab boat to research vessel -- and back -- in record time. Larry Kooker's persistence and labor, aided by Dave Gonzales, were outstanding in the struggle with the minisparker power supplies. We enjoyed working with the mammal observers, who were always willing to share their knowledge. We appreciate Holly Ryan's timely and helpful review of this report. 


\section{REFERENCES CITED}

Bohannon, R. G. and Geist, E., 1998, Upper crustal structure and Neogene tectonic development of the California continental borderland: Geol. Soc. Amer. Bull., v. 110, p. 779-800.

Bohannon, R. G., and Gardner, J.V., 2001, Submarine landslides of San Pedro Sea Valley, southwest Los Angeles Basin, in, Watts, P., Synolakis, C.E., and Bardet, J.P. (Eds.), Prediction of Underwater Slide and Slump Hazards, 14 ms pages. in press.

Bohlen, S. R., Halley, R. B., Hickman, S. H., Johnson, S. Y., Lowenstern, J. B., Muhs, D. R., Plumlee, G. S., Thompson, G. A., Trauger, D. L., and Zoback, M. L., 1998, Geology for a changing world: A science strategy for the Geologic Division of the U.S. Geological Survey, 2000-2010: U.S. Geological Survey Circular 1172, 59p.

Childs, J., Normark, W. R., and Fisher, M. A., 1999, Permit application and approval process for offshore seismic-reflection surveys: U.S. Geological Survey Open-File Report No. 99-572, http://geopubs.wr.usgs.gov/open-file/of99-572/.

Clarke, S. H., and Kennedy, M. P., 1997, Analysis of late Quaternary faulting in the Los Angeles Harbor area and hazard to the Vincent Thomas Bridge: California Dept. of Conservation, Division of Mines and Geology Open-File Report 97-10, 50p, 10 figures, 5 plates.

Clarke, S. H., Greene, H. G., and Kennedy, M. P., 1985, Identifying potentially active faults and unstable slopes offshore: In Ziony, J. I. (Ed.), Evaluating earthquake hazards in the Los Angeles region: an earth-science perspective: U.S. Geological Survey Professional Paper 1360 , p. 347-496.

Crouch, J. K. and Suppe, J., 1993, Late Cenozoic tectonic evolution of the Los Angeles Basin and inner California Borderland: a model for core complex-like crustal extension: Geol. Soc. Amer. Bull., v. 105, 1415-1434.

Dolan, J. F., Sieh, K., Rockwell, T. K., Guptill, P., and Miller, G., 1997, Active tectonics, paleoseismology, and seismic hazards of the Hollywood fault, northern Los Angeles basin, California: Geol. Soc. Amer. Bull., v. 109, p. 1595-1616.

Edwards, B. D., et al., in prep., Cruise report for A1-00-SC Southern California Earthquake Hazards project: U.S. Geological Survey Open-File Report No. XXX, Part B.

Gann, J. T., 1992, YoNav: Your own integrated navigation system for DOS platforms, U.S. Geological Survey Open-File Report 92-565, 62p.

Greene, H. G., and Kennedy, M. P., 1986, Geology of the mid-southern California continental borderland: California Continental Margin Geologic Map Series, California Division of Mines and Geology, Areas 1 and 2, sheets 2, 1:250,000.

Klitgord, K.D., and Brocher, T., 1996, Oblique-slip deformation in the San Pedro Basin offshore Southern California: EOS, Trans. Amer. Geophys. Union, v. 77, p. F737.

Legg, M. R., 1991, Developments in understanding the tectonic evolution of the California Continental Borderland: SEPM Society for Sedimentary Geology Special Publication 46, p. 291-312.

Marlow, M. S., Gardner, J. V., and Normark, W. R., 2000, Using high-resolution multibeam bathymetry to identify seafloor surface rupture along the Palos Verdes fault complex in offshore southern California: Geology, v. 28, p. 587-590.

Normark, W. R., and Piper, D. J. W., 1998, Preliminary evaluation of recent movement on structures within the Santa Monica Basin, offshore southern California: U. S. Geological Survey Open File Report 98-518, 60 p.

Normark, W. R., Bohannon, R. G., Sliter, R., Dunhill, G., Scholl, D. W., Laursen, J., Reid, J. A., and Holton, D., 1999a, Cruise report for A1-98-SC Southern California Earthquake Hazards project: U.S. Geological Survey Open-File Report No. 99-152, 60 p.

Normark, W. R., Reid, J. A., Sliter, R. W., Holton, D, Gutmacher, C. E., Fisher, M. A., and Childs, J. R., 1999b, Cruise report for O1-99-SC Southern California Earthquake Hazards project: U.S. Geological Survey Open-File Report No. 99-560, 60 p.

Pinter, N., Lueddecke, S. B., Keller, E. A., and Simmons, K. R., 1998, Late Quaternary slip on the Santa Cruz Island fault, California: Geol. Soc. Amer. Bull., v. 110, p. 711-722.

Piper, D.J.W., Hiscott, R. N., and Normark, W. R., 1999, Outcrop-scale acoustic facies analysis and latest Quaternary development of Hueneme and Dume submarine fans, offshore California: Sedimentology, v. 46, p. 47-78. 
Rivero, C., Shaw, J. H., and Mueller, K., 2000, Oceanside and Thirtymile Bank blind thrusts: Implications for earthquake hazards in coastal southern California: Geology, v. 28, p. 891894.

Vedder, J. G., 1987, Regional geology and petroleum potential of the Southern California Borderland, In Scholl, D. W., Grantz, A., and Vedder, J. G., eds., Geology and Resource Potential of the Continental Margin of Western North America and Adjacent Ocean Basins -- Beaufort Sea to Baja California, Circum-Pacific Council for Energy and Mineral Resources Earth Science Series, v. 6 (Houston, TX), p. 403-447.

Vedder, J.G., Greene, H.G., Clarke, S.H., and Kennedy, M.P., 1986, Geologic map of the midsouthern California continental margin --- Area 2 of 7, In Greene, H. G. and Kennedy, M. P., eds, 1986, California continental margin geologic map series: Sacramento, CA (California Division of Mines and Geology), scale 1:250,000.

Wallace, R. E., ed., 1990, The San Andreas Fault System, California: U.S. Geological Survey Professional Paper 1515, $283 \mathrm{pp}$.

Ziony, J. I., and Yerkes, R. F., 1985, Evaluating earthquake and surface-faulting potential: In Ziony, J. I. (Ed), Evaluating earthquake hazards in the Los Angeles region: an earth-science perspective: U.S. Geological Survey Professional Paper 1360, p. 43-91. 
Table 1. Scientific Personnel

\begin{tabular}{|c|c|c|}
\hline $\begin{array}{c}\text { Crew Person } \\
\text { (dates embark and disembark) }\end{array}$ & Crew Affiliation & Crew Responsibilities \\
\hline Chris Gutmacher (1) & USGS & Co-Chief, watchstander \\
\hline Stephanie Ross (3) & USGS & Co-Chief, watchstander \\
\hline Brian Edwards (4) & USGS & Co-Chief Scientist \\
\hline Larry Kooker (1) & USGS & ET \\
\hline Kevin O'Toole (2) & USGS & MT \\
\hline Ray Sliter (1) & USGS & MCS Watchstander \\
\hline Becky Cooper (1) & USGS & Watchstander, Navigation \\
\hline Pat Hart (3) & USGS & MCS Watchstander \\
\hline Jon Childs (4) & USGS & MCS Watchstander \\
\hline Dave Gonzales (2) & USGS & ET \\
\hline Jane Reid (5) & USGS & Watchstander \\
\hline Dave Hogg (4) & USGS & ET \\
\hline Tim Elfers (4) & USGS & MT \\
\hline Walt Olson (4) & USGS & MT \\
\hline Martin Uyesugi (1) & Geoforce Consultants & Huntec engineer, watchstander \\
\hline Annie Douglas (1) & Cascadia Research & Mammal Observer \\
\hline Lisa Baraff (1) & Cascadia Research & Mammal Observer \\
\hline Dave Ellifrit (1) & Cascadia Research & Mammal Observer \\
\hline Todd Chandler (1) & Cascadia Research & Lead, Mammal Observer Team \\
\hline JR Veldink (1) & Cascadia Research & Mammal Observer \\
\hline Dick Corrigan (2) & Northwind Shipyards & Captain \\
\hline Ted Blinkers (4) & Northwind Shipyards & Captain \\
\hline Jeffrey "Striker" Stringer (1) & Northwind Shipyards & Mate \\
\hline James "Sparky" Stacey (1) & Northwind Shipyards & Engineer \\
\hline Ricky Labrador (1) & Northwind Shipyards & Cook \\
\hline Rich Soderblom (1) & Northwind Shipyards & Deck Hand, everything else \\
\hline Brad Scarrott (6) & Applied Acoustic Eng. & Minisparker doctor \\
\hline
\end{tabular}
(1) 5-29 June
(2) 5-20 June
(3) 7-20 June
(4) 20-29 June
(5) 5-7 June
(6) 22-25 June 
Table 2. Operational Log

Local time is 7 hours behind Julian Day (JD) and Greenwich Mean Time (GMT)

June 5, $2000=$ JD 157

Dawn about 0530 local $=1230 \mathrm{z}$

Dark about 2030 local $=0330 \mathrm{z}$ next JD

\begin{tabular}{|c|c|}
\hline $\begin{array}{l}\text { DATE/TIME } \\
\text { JD/GMT }\end{array}$ & ACTIVITY \\
\hline $157 / 1700$ & Depart USGS Marine Facility, Port of Redwood City \\
\hline $159 / 0345-1630$ & $\begin{array}{l}\text { At Port Hueneme for repair of ship's gyro and personnel transfer. Test } \\
\text { minisparker over the side, smoke the power supplies, repair them }\end{array}$ \\
\hline 159/1726-2006 & $\begin{array}{l}\text { Rendezvous with Blue Skies and participate in sound-source calibration } \\
\text { experiments conducted by Greenridge Associates }\end{array}$ \\
\hline $159 / 2339$ & Begin Leg 1 survey with Huntec, minisparker, and $12 \mathrm{kHz}$ \\
\hline $160 / 0200$ & Approx. time minisparker power supplies fail, continue with Huntec \\
\hline $160 / 1607-1646$ & Shutdown of acoustic sources called by "mammal team" \\
\hline $160 / 1825$ & Huntec off for minisparker test \\
\hline $160 / 1830-2025$ & Minisparker test, power supplies fail again \\
\hline $160 / 2030$ & Huntec on \\
\hline $160 / 2110-2210$ & Huntec off, switch gear, Geopulse on \\
\hline $162 / 0244-0320$ & $\begin{array}{l}\text { Geopulse off; replace multichannel (MC) streamer tail buoy destroyed by } \\
\text { pleasure boat }\end{array}$ \\
\hline $162 / 1007-1009$ & Shutdown called by "mammal team" \\
\hline $162 / 1140-1146$ & Shutdown called by "mammal team" \\
\hline $162 / 1915-1922$ & Shutdown called by "mammal team" \\
\hline $162 / 2126$ & Geopulse off for minisparker test \\
\hline $162 / 2130-2155$ & Minisparker test; terminated when one power supply smoked \\
\hline $162 / 2245$ & Geopulse on \\
\hline $162 / 2344-2353$ & Shutdown called by "mammal team" \\
\hline $163 / 1526-1646$ & Geopulse off to remove kelp, vet geopulse sled, replace tail buoy again \\
\hline $163 / 1946-1948$ & Geopulse off, switch gear, Huntec on \\
\hline $163 / 2234-2305$ & Shutdown called by "mammal team" \\
\hline $164 / 0301-0312$ & Huntec off, switch gear, Geopulse on \\
\hline $164 / 0524$ & Geopulse off for minisparker test \\
\hline $164 / 0530-0558$ & $\begin{array}{l}\text { Minisparker test using } 220 \text { power from ship-power supplies smoked } \\
\text { again, running out of spares and ideas }\end{array}$ \\
\hline
\end{tabular}




\begin{tabular}{|c|c|}
\hline $164 / 0623$ & Geopulse on \\
\hline $164 / 0701-0732$ & Geopulse off while removing crab pots from $12 \mathrm{kHz}$ \\
\hline $164 / 1217-1259$ & 12-kHz system off (too shallow to tow safely, use bridge's fathometer) \\
\hline $164 / 1642-1702$ & Geopulse off for kelp removal \\
\hline $164 / 1827-1900$ & Geopulse off to remove kelp from it and from MC streamer tail buoy \\
\hline $164 / 2107-2126$ & 12-kHz system off (too shallow to tow safely, use bridge's fathometer) \\
\hline $164 / 2216-2230$ & $\begin{array}{l}\text { Shutdown called by "mammal team". Whale sighted, so night ops } \\
(0330-1230) \text { will stay in water deeper than } 50 \mathrm{~m} \text {. }\end{array}$ \\
\hline $165 / 0009$ & $\begin{array}{l}\text { Geopulse off; retrieve gear, send skiff to Seaside harbor for gyro repair } \\
\text { man }\end{array}$ \\
\hline $165 / 0253$ & Resume survey with Geopulse and $12 \mathrm{Khz}$ systems. \\
\hline $165 / 0432$ & $\begin{array}{l}\text { Geopulse off; retrieve gear, and after lengthy delay to work on auto-pilot, } \\
\text { send skiff to deliver repair man. } \\
\text { Whale sighting results in plan to Huntec in water }>50 \mathrm{~m} \text { this night }\end{array}$ \\
\hline $165 / 0847$ & Resume survey with Huntec and $12 \mathrm{Khz}$ systems \\
\hline $165 / 2339-2345$ & $\begin{array}{l}\text { Shutdown called by "mammal team". Whale sighted, so night ops } \\
(0330-1230) \text { will stay in water deeper than } 50 \mathrm{~m} \text {. }\end{array}$ \\
\hline $166 / 0130-0155$ & Huntec off, switch gear, Geopulse on \\
\hline $166 / 0540-0556$ & Shutdown called by "mammal team" \\
\hline $166 / 0735-0828$ & Shutdown called by "mammal team" \\
\hline $166 / 1135-1204$ & Geopulse off, switch gear, Huntec on \\
\hline $166 / 2000-2021$ & Huntec off, switch gear, Geopulse on \\
\hline $166 / 2041-2338$ & Power down; spiking voltage, check generator, eventually switch gen. \\
\hline $166 / 2340$ & Resume survey with Geopulse and $12 \mathrm{kHz}$ \\
\hline 167/0306-0310 & Shutdown called by "mammal team" \\
\hline 167/0841-0858 & Geopulse off, switch gear, Huntec on \\
\hline $167 / 1159-1206$ & Shutdown called by "mammal team" \\
\hline $167 / 1258-1303$ & Shutdown called by "mammal team" \\
\hline $167 / 1334-1336$ & Shutdown called by "mammal team" \\
\hline $167 / 1615-1618$ & Shutdown called by "mammal team" \\
\hline $167 / 1737-1742$ & Shutdown called by "mammal team" \\
\hline $167 / 2246-2309$ & Huntec off; trigger problems \\
\hline $168 / 0030-0052$ & Huntec off, switch gear, Geopulse on \\
\hline $168 / 0628-0635$ & Shutdown called by "mammal team" \\
\hline 168/0726-0734 & Shutdown called by "mammal team" \\
\hline $168 / 1347$ & Geopulse off; recover gear for transit to San Diego \\
\hline
\end{tabular}




\begin{tabular}{|c|c|}
\hline $168 / 1545-1715$ & $\begin{array}{l}\text { Port call in San Diego (use Scripps Institution of Oceanography Marine } \\
\text { Facility pier) to pick up new power supply (built in England) and cable for } \\
\text { the minisparker system }\end{array}$ \\
\hline $168 / 1932$ & Resume survey with Geopulse and $12 \mathrm{kHz}$ \\
\hline $169 / 0405$ & Geopulse off; prepare for test of new power supply for minisparker \\
\hline $169 / 0430-0453$ & Minisparker test \\
\hline 169/0453-0459 & Shutdown called by "mammal team" \\
\hline $169 / 0459-0722$ & Continue minisparker testing \\
\hline $169 / 0752-0913$ & Test simultaneous and asynchronous firing of minisparker with Huntec \\
\hline $169 / 0926$ & Huntec off \\
\hline 169/0934-1006 & Minisparker alone on comparison line \\
\hline 169/1013-1032 & Huntec alone on comparison line \\
\hline $169 / 1037-1203$ & Use minisparker alone until power supply dies \\
\hline $169 / 1208$ & Huntec on \\
\hline $169 / 1340-1357$ & Huntec off, switch gear, Geopulse on \\
\hline $169 / 1433$ & Huge kelp crisis, must recover, clear kelp from all gear incl. MC streamer \\
\hline $169 / 1650$ & Resume survey with Huntec and $12 \mathrm{kHz}$ \\
\hline $170 / 0325-0329$ & Shutdown called by "mammal team" \\
\hline $170 / 0417-0422$ & Shutdown called by "mammal team" \\
\hline $170 / 0445-0455$ & Shutdown called by "mammal team" \\
\hline 170/1153-1159 & Shutdown called by "mammal team" \\
\hline $170 / 1636-1639$ & Shutdown called by "mammal team" \\
\hline $170 / 1750-1850$ & $\begin{array}{l}\text { Marty running Huntec tests while ship's engine oil changed (noisy record } \\
\text { while using only one engine) }\end{array}$ \\
\hline $171 / 0200$ & Huntec off for test of minisparker system \\
\hline $171 / 0223-0235$ & Minisparker test \\
\hline $171 / 0235-0252$ & Shutdown called by "mammal team" \\
\hline $171 / 0252-0327$ & Huntec on between minisparker tests \\
\hline $171 / 0328-0355$ & $\begin{array}{l}\text { Minisparker test with new cable and "real" } 220 \text { from transformer--blue } \\
\text { flame shoots out--decide to wait for engineer and spares }\end{array}$ \\
\hline $171 / 0413$ & Huntec on \\
\hline $171 / 1953-2011$ & Huntec off, switch gear, Geopulse on \\
\hline $171 / 2159$ & Geopulse and $12 \mathrm{kHz}$ off; retrieve gear for transit to Newport area \\
\hline $172 / 0221$ & Huntec and $12 \mathrm{kHz}$ on \\
\hline $172 / 0534-0539$ & Shutdown called by "mammal team" \\
\hline $172 / 0803-0807$ & Shutdown called by "mammal team" \\
\hline
\end{tabular}




\begin{tabular}{|c|c|}
\hline 172/1203-1204 & Huntec off, switch gear, Geopulse on \\
\hline $172 / 1342-1344$ & Geopulse off, switch gear, Huntec on \\
\hline $172 / 1350-1354$ & Shutdown called by "mammal team" \\
\hline $172 / 1702$ & $\begin{array}{l}\text { Huntec and } 12 \mathrm{kHz} \text { off; retrieve gear, transit to San Pedro for personnel } \\
\text { transfer before starting survey for salt water intrusion of aquifers on Long } \\
\text { Beach shelf and harbor area }\end{array}$ \\
\hline \multirow[t]{2}{*}{$\begin{array}{l}172 / 1915- \\
173 / 0150\end{array}$} & $\begin{array}{l}\text { Port call at San Pedro berth 93B. Repair } 1 \text { generator, get groceries, swap } \\
\text { out several science crew and ship's captain (see Table 1). }\end{array}$ \\
\hline & $\operatorname{Leg} 2$ \\
\hline $173 / 0413$ & Begin Leg 2, aquifer study; Huntec and $12 \mathrm{kHz}$ on \\
\hline $173 / 0632-0636$ & Shutdown called by "mammal team" \\
\hline $173 / 0658-0702$ & Shutdown called by "mammal team" \\
\hline $173 / 0714-0720$ & Shutdown called by "mammal team" \\
\hline $173 / 1549$ & Huntec off, prepare to test Uniboom along same line \\
\hline 173/1622-1747 & Uniboom system on along test line \\
\hline $173 / 1816$ & Geopulse on along test line, like it best so continue \\
\hline $174 / 0456$ & $12 \mathrm{kHz}$ off; retrieve tow fish for very shallow shelf and harbor work \\
\hline $174 / 1852$ & Geopulse off, retrieve all gear for U-turn in narrow harbor channel \\
\hline $174 / 1942$ & Geopulse on, collect data while underway in harbor channel \\
\hline $174 / 2325-2355$ & $\begin{array}{l}\text { Geopulse off; port touch and go to pick up engineer and spare parts from } \\
\text { Applied Acoustics to work on minisparker power-supply problems }\end{array}$ \\
\hline $175 / 0218$ & Geopulse on, resume survey \\
\hline $175 / 0317$ & $\begin{array}{l}\text { Whale sighted, must change plans and move to deeper-water }(>50 \mathrm{~m}) \\
\text { area for night ops, Geopulse off for transit }\end{array}$ \\
\hline $175 / 0539$ & Huntec and $12 \mathrm{kHz}$ on, resume survey \\
\hline $175 / 0821-0823$ & Shutdown called by "mammal team" \\
\hline $175 / 1326-1346$ & Huntec off, retrieve $12 \mathrm{kHz}$ for harbor work, switch gear, Geopulse on \\
\hline $175 / 1829$ & Geopulse off for minisparker tests \\
\hline $175 / 1855-2306$ & Minisparker on \\
\hline $175 / 2312-2322$ & Port touch and go to get last box of minisparker spares \\
\hline $175 / 2327$ & Continue minisparker lines \\
\hline $176 / 1317$ & Minisparker off to deploy MC streamer \\
\hline $176 / 1317-1318$ & Shutdown called by "mammal team" \\
\hline $176 / 1350$ & Continue minisparker, breaking, repairing, retesting power supplies \\
\hline $177 / 1900$ & Minisparker off to drop off Brad (engineer). New power supply stable \\
\hline $177 / 2000-2010$ & Port touch and go to let Brad off \\
\hline
\end{tabular}




\begin{tabular}{|l|l|}
\hline $177 / 2055$ & Minisparker on \\
\hline $177 / 2109$ & Launch $12 \mathrm{kHz}$ on shelf \\
\hline $177 / 2241$ & $12 \mathrm{kHz}$ off for more shallow water ops \\
\hline $178 / 0255$ & $\begin{array}{l}\text { Whale sighted, must change plans and move to deeper-water area for } \\
\text { night; minisparker off and retrieve gear for transit }\end{array}$ \\
\hline $178 / 0552$ & Huntec and 12 kHz on in deeper water \\
\hline $178 / 0605-0607$ & Shutdown called by "mammal team" \\
\hline $178 / 0945$ & Huntec and 12 kHz off; retrieve gear for transit to N. Santa Monica Bay \\
\hline $178 / 1246$ & Minisparker and 12 kHz on \\
\hline $179 / 0130$ & Minisparker off, problem with MC streamer; switch gear \\
\hline $179 / 0155$ & Huntec on \\
\hline $179 / 1158-1203$ & Shutdown called by "mammal team" \\
\hline $179 / 1304-1307$ & Shutdown called by "mammal team" \\
\hline $179 / 1658-1716$ & Shutdown called by "mammal team" \\
\hline $179 / 1659$ & 12 kHz off for calibrated hydrophone listening tests \\
\hline $179 / 1716$ & Begin listening test with Huntec \\
\hline $179 / 1729-1739$ & Huntec off; switch gear, Geopulse on \\
\hline $179 / 1751$ & Geopulse off; sound test over, deploy MC streamer \\
\hline $179 / 1805$ & Minisparker on, test streamer \\
\hline $179 / 1830-1833$ & Shutdown called by "mammal team" \\
\hline $179 / 1847-1854$ & Shutdown called by "mammal team" \\
\hline $179 / 1854$ & Huntec and 12 kHz on for last line (done with MC streamer test ) \\
\hline $179 / 1859-1906$ & Shutdown called by "mammal team" \\
\hline $179 / 1920-1922$ & Shutdown called by "mammal team" \\
\hline $179 / 2045$ & End of survey; retrieve all gear; prepare to head to Redwood City \\
\hline $181 / 0645$ & Arrive Port of Redwood City after fast, smooth 34-hr transit "up hill" \\
\hline
\end{tabular}




\title{
Appendix 1
}

\section{USGS OF 00-516}

\author{
Report prepared by \\ Cascadia Research \\ Under contract to the USGS in support of \\ Cruise A1-00-SC
}

(The following report has been formatted to fit on fewer pages than the original, and paginated as a continuation of OF 00-516. No text or content changes were made.) 


\title{
FINAL REPORT
}

\section{MARINE MAMMAL OBSERVATIONS AND MITIGATION ASSOCIATED WITH USGS SEISMIC SURVEYS IN THE SOUTHERN CALIFORNIA BIGHT IN 2000}

\author{
Prepared for \\ U.S. Geological Survey \\ 345 Middlefield Rd. \\ Menlo Park CA 94025
}

\author{
Prepared by \\ John Calambokidis \\ Todd Chandler \\ Cascadia Research \\ 218-1/2 W Fourth Ave. \\ Olympia, WA 98501
}

December 2000 


\section{TABLE OF CONTENTS}

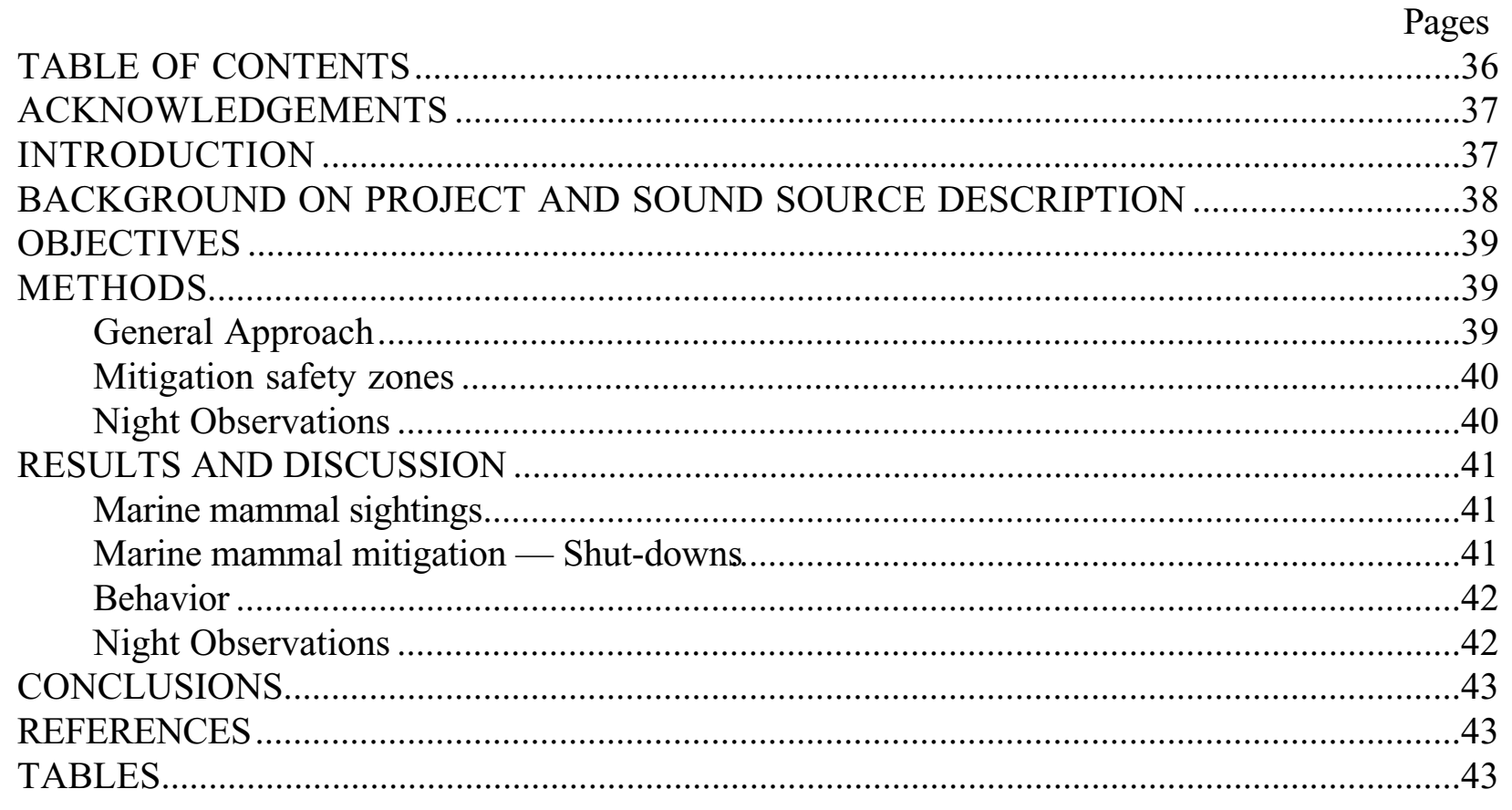




\section{ACKNOWLEDGEMENTS}

Lisa Baraff, Annie Douglas, JR Veldink, and Dave Ellifrit assisted Todd Chandler as marine mammal observers on the survey. Lisa Schlender computer coded the data gathered in the field. Support for the marine mammal observations was provided by the US Geological Survey. The National Marine Fisheries Service provided a permit for the research. Our thanks to the USGS personnel who assisted including Chris Gutmacher, Jon Childs, Bill Normark, and Mike Fisher. We thank the crew of the Auriga for their help.

\section{INTRODUCTION}

From 7 to 27 June 2000, the U.S. Geological Survey conducted seismic surveys in the coastal waters of the Pacific Ocean, in the southern California Bight, to investigate earthquake hazards. As a part of this project, Cascadia Research was contracted by the USGS to monitor marine mammals from the survey platform and provide mitigation on impacts on marine mammals by requesting shutdown of the sound sources when marine mammals were close to the operations.

This report summarizes the results of a marine mammal mitigation and monitoring program conducted in conjunction with these USGS surveys and adds information to similar work conducted by Cascadia Research in 1998 and 1999 (Calambokidis et al 1998, Quan and Calambokidis 1999). There were several modifications to observations and mitigation operations in 2000 compared to 1999 and 1998: 1) five observers were on board with at least two on duty during all daylight and nighttime operations, 2) the mitigation safety zone was slightly more complicated and involved multiple sound sources, and 3) airgun operations were conducted during the night time hours if baleen whales had not been seen in the area during the day. 


\section{BACKGROUND ON PROJECT AND SOUND SOURCE DESCRIPTION}

The following background on the overall project and sound source description was provided by the USGS.

The focus of this project is to identify the landslide and earthquake hazards, as well as related deformation processes, that have great potential to impact the social and economic well being of the inhabitants of the Southern California coastal region--the most heavily populated urban corridor along the U.S. Pacific margin. We are studying PleistoceneHolocene sedimentation and deformation patterns and related seismicity and strain within the coastal zone and adjacent continental borderland basins. Our findings will help us evaluate the hazard potential for large, destructive earthquakes and identify how deformation is distributed in space and time between onshore and offshore regions. The results of this project will contribute to decisions involving land use, hazard zonation, and building codes in the area.

The FY 2000 field program was conducted using a leased vessel, the 156-ft-long M/V Auriga, owned and operated by F/V North Wind, Inc. Three sound sources were used:

Minisparker: The sound source for the multi-channel seismic-reflection (MCS) profiling during the cruise was a $1.5 \mathrm{kJoule}(\mathrm{kJ})$ "SQUID 2000" minisparker system manufactured by Applied Acoustic Engineering, Inc. This minisparker consists of eight sets of discharge electrodes, in two banks, mounted on a small pontoon sled. The pontoon sled that supports the minisparker is towed on the sea surface, generally about 3 meters behind the ship. Source characteristics of the SQUID $2000^{\mathrm{TM}}$ provided by the manufacturer show a sound-pressure level (SPL) of $209 \mathrm{~dB}$ re 1 Pa-m RMS. The amplitude spectrum of this pulse indicates that most of the sound energy lies between $150 \mathrm{~Hz}$ and $1700 \mathrm{~Hz}$, and the peak amplitude is at $900 \mathrm{~Hz}$. The output sound pulse of the mini-sparker has a duration of about $0.8 \mathrm{~ms}$. For the multichannel seismic-reflection survey, the minisparker was discharged every 2 seconds, and when used with a single-channel streamer, at $400 \mathrm{~J}$, the fire rate varied from $300-750 \mathrm{~ms}$, depending on water depth.

Huntec: A high-resolution Huntec DTS boomer system towed between $20 \mathrm{~m}$ and $137 \mathrm{~m}$ below the sea surface (depending upon the water depth) was used to image the upper few tens of milliseconds of strata with a resolution of better than $0.5 \mathrm{~ms}(0.4 \mathrm{~m})$. The SPL for this source is $210 \mathrm{~dB}$ re 1 Pa-m RMS. Power output was 375 Joules, with a firing rate that was also dependent on water depth, ranging from $0.5 \mathrm{sec}$ over the shelf and upper basin slopes to $1.67 \mathrm{sec}$ over the deeper parts of the basins.

Geopulse: The sound source consists of two ORE Geopulse 5813A boomer plates mounted on a catamaran sled built in-house. The catamaran was towed from the same deck area as the multichannel sound source, while the short hydrophone streamer was towed from a boom on the starboard side of the vessel. The source level suggested by the manufacturer is $220 \mathrm{~dB}$ re $1 \mathrm{~Pa}-\mathrm{m}$ RMS. Power input was 350 Joules, with a firing rate that was also dependent on water depth: 0.5 or 1.0 second for the geologic hazard part of the survey and 0.25 second in the harbor areas. 


\section{OBJECTIVES}

The objectives of the marine mammal study were as follows:

1. Mitigate impacts on marine mammals by monitoring the presence of these species from the survey ship and requesting shut-down of the sound source when marine mammals were seen within specified safety zones representing distances close enough to potentially cause physical injury.

2. Document the number of animals of each species present in the vicinity of sound transmissions.

3. Evaluate the reactions of marine mammals to the sound transmissions at different distances from the sound source.

\section{METHODS}

\section{General Approach}

The research effort consisted of observations made directly from the seismic vessel (Auriga) to provide mitigation, document marine mammals exposed to the sound sources, and monitor reactions of marine mammals close to the seismic survey vessel. Observations were conducted from several locations. The primary platform utilized by one of the two on-duty observers during both day and night operations was in front of the bridge and put the observer's eye level at $7.6 \mathrm{~m}$ above the water. This external platform provided excellent visibility to the front and sides but obscured visibility to the rear. The platform was near the front of the vessel $6.4 \mathrm{~m}$ behind the bow and $47 \mathrm{~m}$ from the stern of the vessel. During daylight observations, a second observer used a platform immediately behind the bridge that faced aft and put the observer eye level at about $10 \mathrm{~m}$ above the water. This station was used to view the area to the rear of the bridge and immediately around the sound source. During night observations the second observer roamed the vessel's main external deck just above water level.

Observations were conducted 24 hours a day when seismic operations were underway. Two observers were on watch at all times on rotating shifts among the total of five observers on the boat. Observers shifted every two hours. During daylight observations, observers used Tasco $7 \times 50$ binoculars with internal compasses and reticles to record the horizontal and vertical angle to sightings. Night-time operations used a commercial night vision goggles (see next section). The roaming observer that was responsible for the sides and rear portion of the ship had the benefit of lights that illuminated the rear deck and aft of the ship.

Data on survey effort and sightings were recorded on a datasheet which included observers on duty and weather conditions (Beaufort sea state, wind speed, cloud cover, swell height, precipitation, visibility, etc.). For each sighting the time, bearing and reticle reading to sighting, species, group size, surface behavior and orientation were recorded. A polaris was used to determine the angle to the sighting in relation to the ship's course. 
Distances to sightings were calculated using the vertical angle to the animal (based on either the reticle reading through the binoculars or a hand held clinometer for close sightings) and the known elevation above the water.

\section{Mitigation safety zones}

Two safety zones were used for this project. These were:

1. For pinnipeds and odontocetes (all toothed cetaceans except sperm whales) seismic operations would be shut down when an animal was seen close to a distance of $30 \mathrm{~m}$ or less.

2. For mysticetes (baleen whales) and sperm whales, the safety zone was $250 \mathrm{~m}$.

To allow a quick determination of status, safety zones were calculated in three arcs around the ship and the safety distance was applied using the closest part of the ship or sound source. Three different cut-off distances (based on distance and angle from the observers) were calculated for off the bow (60 degrees to either side of the bow), to either side of the vessel (from 60 to 120 degrees off the bow and off the stern (120 to 180 degrees off the bow).

Observers were instructed to call for a shut-down when a marine mammal was seen inside the safety zone or close enough to the safety zone that given measurement-error, it could be within the safety zone. Shut-down was also considered when animals were ahead of the vessel path outside the safety zone, but it appeared likely that the direction of travel of the vessel would result in the marine mammal being within the safety zone shortly. If possible, marine mammals were tracked until they were outside the safety zone at which time seismic operations resumed. If animals could not be tracked then seismic operations were resumed after there were no resightings of animals within the safety zone for a period adequate to indicate these animals were not any longer near the ship.

For effective mitigation, the observers needed to know very quickly whether a sighting was within the safety zone. We used a polaris (angle board) for the observers to estimate the angle to the sighting. The cut-off vertical angle, which represented each of the safety zones, was also written on the polaris, allowing quick determination of the proximity of a sighting to the safety zone.

\section{Night Observations}

Several modifications were made for night observations during seismic operations. Due to the reduced visibility at night, the two observers focused on sightings of marine mammals in the immediate vicinity of the ship. One observer would observe the forward part of the ship from the platform forward of the bridge and the second would roam the sides and aft portion of the shift primarily observing aft near the sound source. Generation-3 night vision goggles (ITT Industries) were used to assist in sightings primarily by the forward observer. Distances to sightings could not easily be determined with clinometers or binoculars and were instead estimated. 
As a mitigation to avoid exposure to mysticete (baleen) or large odontocetes (toothed) whales during night operations, additional precautions were taken. Because sightings of these species out at the mitigation distance of $250 \mathrm{~m}$ was not possible, night operations were conducted only if no large whales had been seen in the region during the daylight operations.

\section{RESULTS AND DISCUSSION}

\section{Marine mammal sightings}

There were a total of 241 sightings (not including re-sightings), representing at least 11 species and comprised of 4,792 marine mammals made during observation operations (Table 1). Small cetaceans were the most numerous and common marine mammal species sighted accounting for $54 \%$ of the sightings and $96 \%$ of the animals. Common dolphins were the most common small cetacean species with 74 sightings of 3,764 animals. Risso's dolphins, bottlenose dolphins, and Dall's porpoise were also seen in smaller numbers. Pinnipeds accounted for 98 sightings and these were predominantly California sea lions. Smaller numbers of harbor seals and a single elephant seal were also sighted. Four species of large cetacean were sighted in small numbers including blue, fin, humpback, and minke whales. Blue whales were the most common with five sightings of single animals.

Sightings of marine mammals were made during a wide variety of operational states for the various sound sources (Table 2). Rates at which marine mammals were sighted were different among the different operational modes likely due to habitat differences. California sea lion sightings were made almost twice as often during operation of the minisparker than they were during other operating modes. Conversely, common dolphin sightings occurred during Huntec operations at more than twice the rate of other operating modes. These differences likely reflect the differences in where these sound sources were used: minisparker on the shelf and near LA/Long Beach Harbor and the Huntec in more offshore waters.

\section{Marine mammal mitigation - Shut-downs}

Shut-down of the sound source was requested in 40 instances (22 daylight and 18 night) (Table 3). Shut-downs were called for during a variety of sound source operations including 19 during Huntec and 12 during Geopulse operation. Shut-downs were called in response to five different species (in one case the dolphin species was not determined). Common dolphins were the most common species triggering a shut-down accounting for 29 instances. Risso's and bottlenose dolphins and California sea lions each accounted for three or four shut-downs each. The only shut-down for a large whale was for a sighting of a blue whale which was still outside the $250 \mathrm{~m}$ mitigation zone but which prompted a precautionary shut-down.

The high proportion of shut-downs caused by common dolphins was a result both of their being one of the most common species in the area and their tendency to approach the ship. Common dolphins accounted for $31 \%$ of the marine mammal sightings but were responsible for $72 \%$ of the shut-downs. California sea lions, which accounted for $36 \%$ of the sightings were responsible for only $7 \%$ of the shut-downs. Although other dolphin species were less common, both Risso's and bottlenose dolphins had shut-down rates that were similar to common dolphins. 
Overall, $30 \%$ of small cetacean sightings made while sound sources were operational led to shutdowns compared to only $4 \%$ of pinniped sightings (Table 4 ). A low proportion of large whale sightings led to shut downs. The 11 sightings of whales made during sound source operations led to only the single precautionary shut-down (outside the mitigation area) for the blue whale mentioned above. This low rate is partly the result of the much greater distance at which large whales could be sighted.

The proportion of sightings that led to shut-downs did not seem to vary greatly by what sound source was operating (Table 5). About $20 \%$ of small cetaceans sightings during daylight observations lead to a shut-down regardless of sound source operating. Similarly, about $4 \%$ of daylight sightings of pinnipeds lead to shut-downs regardless of sound source. These findings suggest that there were not large differences in how marine mammals were attracted to or avoided the ship when different sound sources were operating.

\section{Behavior}

Marine mammals were observed in a variety of behaviors regardless of sound source operation (Table 6). Primary behavior was slow or fast travel, hauled out, or milling. Fast travel was the most common behavior for common dolphins during both times sound was transmitting and when it was not. Pinnipeds were most commonly seen hauled out or slow traveling. Breaching was seen in two cases for large cetaceans; a minke whale and a group of two humpback whales. Sound transmissions were occurring only for the minke whale sighting.

Orientation of marine mammals in relation to the boat at initial sighting did not appear to vary by sound transmissions (Table 7). Most marine mammals were not judged to be headed toward or away from the survey vessel but on a tangent. This was the case both during transmissions and when there were none. Of those that were judged to be moving toward or away from the vessel, a slightly higher proportion of animals tended to be headed toward the vessel compared to away. This again held true both when sound sources were on or off. Overall, we could not detect differences in orientation of marine mammals in relation to transmissions.

\section{Night Observations}

Some aspects of the night operations were discussed above. Overall there were dramatically reduced numbers of sightings of marine mammals at night (Table 5). Sightings at night were primarily of dolphins that approached the boat closely. In all but one case the animals were $100 \mathrm{~m}$ or closer from the boat when initially sighted. The close distance at which marine mammals could be seen at night resulted in shut-downs in 18 of 29 cases where small cetaceans were seen at night during sound transmissions. Sightings of both pinnipeds and larger cetaceans were dramatically reduced at night since these species did not approach the boat closely as often. There were no large cetacean sightings at night and only six pinniped sightings at night (compared to 92 in the day).

Despite the difficulty in sighting marine mammals at night, the observers were successful in sighting marine mammals within the safety on 18 occasions resulting in shut-downs. Despite the low sighting rate, the observers were able to provide some mitigation and reduced the potential exposure of bow-riding dolphins to elevated sound levels. Despite the use of a variety 
of generation 3 night-vision gear, it was not possible to sight marine mammals at distances greater than $100 \mathrm{~m}$. Mitigating exposure through the $250 \mathrm{~m}$ safety zone for large cetaceans was therefore not practical. We were not able to evaluate whether the precaution of conducting operations at night only in areas where large cetaceans had not been seen in the day was completely effective as a mitigation strategy.

\section{CONCLUSIONS}

Overall marine mammal monitoring and mitigation appeared successful in meeting the objectives of the study. There were more shut-downs in 2000 compared to either 1998 or 1999 and even though these provided effective mitigation, they interrupted the objectives of the seismic survey. Most of the shut-downs were from common dolphins, a species that was sighted more often in 2000 than in 1998 and 1999, but this increased sighting rate was not enough to account for the difference. Additionally, the safety zone for pinnipeds and small cetaceans in 1998 and 1999 was $100 \mathrm{~m}$, greater than the $30 \mathrm{~m}$ zone used in 2000 . Shut-downs at night were a principal reason for the higher number of total shut-downs in 2000. In 1999 there were no night operations. In 1998 there were night operations but only two shut-downs called at night compared to 18 in 2000. Sighting conditions in 1998 were not as good with only one observer on duty and inferior night vision gear to that used in 2000. That combined with a lower presence of dolphins in the study area likely accounted for the difference between 1998 and 2000.

\section{REFERENCES}

Calambokidis, J. L. Schlender, and J. Quan. 1998. Marine mammal observations and mitigation associated with USGS surveys in the southern California Bight in 1998. Final Report to U.S. Geological Survey, Menlo Park, California. Cascadia Research, 218-1/2 W Fourth Ave., Olympia, WA 98501. 14pp.

Quan, J., and J. Calambokidis. 1999. Marine mammal observations and mitigation associated with USGS seismic surveys in the southern California Bight in 1999. Final Report to U.S. Geological Survey, Menlo Park, California. Cascadia Research, 218-1/2 W Fourth Ave., Olympia, WA 98501. 16pp.

\section{TABLES}

1. Summary of sightings and resightings by species

2. Sightings by species and operational state

3. List of shut-downs called during the survey

4. Percent of sightings resulting in shut-downs during sound transmissions

5. Summary of effort, sightings and shutdowns by operational state and day/night

6. Summary of primary behavior by species

7. Summary of orientation by species 
Table 1. Summary of sightings and resightings by species in 2000. Resightings represent groups seen more than one time. Does not include sightings outside study area during transit to and from region.

\begin{tabular}{|c|c|c|c|c|}
\hline & \multicolumn{2}{|c|}{ Sighting } & \multicolumn{2}{|c|}{ Resighting } \\
\hline Species & \# of Sightings & \# of Animals & \# of Sightings & \# of Animals \\
\hline \multicolumn{5}{|l|}{ Large whales } \\
\hline Blue whale & 5 & 5 & 4 & 4 \\
\hline Fin whale & 1 & 1 & 2 & 2 \\
\hline Humpback whale & 1 & 2 & & \\
\hline Large Balaenopterid & 1 & 1 & 2 & 2 \\
\hline Minke whale & 2 & 3 & 2 & 4 \\
\hline Unidentified whale & 2 & 2 & & \\
\hline Total whales & 12 & 14 & 10 & 12 \\
\hline \multicolumn{5}{|l|}{ Small cetaceans } \\
\hline $\begin{array}{l}\text { Common dolphin (short \& long- } \\
\text { beaked) }\end{array}$ & 74 & 3764 & 20 & 2047 \\
\hline Risso's dolphin & 14 & 120 & 4 & 35 \\
\hline Dall's porpoise & 2 & 2 & & \\
\hline Bottlenose dolphin & 10 & 82 & 4 & 41 \\
\hline Unidentified dolphin & 31 & 627 & 1 & 55 \\
\hline Total small cetaceans & 131 & 4595 & 29 & 2178 \\
\hline \multicolumn{5}{|l|}{ Pinnipeds } \\
\hline California sea lion & 87 & 171 & 4 & 10 \\
\hline Elephant seal & 1 & 1 & & \\
\hline Harbor seal & 7 & 8 & & \\
\hline Unidentified pinniped & 3 & 3 & & \\
\hline Total pinnipeds & 98 & 183 & 4 & 10 \\
\hline Grand Total & 241 & 4792 & 43 & 2200 \\
\hline
\end{tabular}


Table 2. Summary of sightings by operational condition and species within study area in 2000 .



Other effort with no sightings:

Total of $.9 \mathrm{~h}$ covering $2.5 \mathrm{nmi}$ with both Geopulse and Sparker on

Total of $6 \mathrm{~h}$ and $14.3 \mathrm{nmi}$ with both Huntec and Sparker on

Also $15 \mathrm{~h}$ covering $144 \mathrm{nmi}$ of effort outside study area with no sources not included above (some sightings) 
Table 3. List of shut-downs called for based on sightings of marine mammals during 2000 surveys.

\begin{tabular}{|c|c|c|c|c|c|c|c|c|c|c|}
\hline & & & & Time & & & & & & \\
\hline Date & Firing & Dy/Nt & Sight & Sht-dn & Resume & Tot. \# & Species & Sit. \# & Obs & Comments \\
\hline 08-Jun-00 & Huntec & D & 0902 & 0902 & 0950 & 1 & Common dolphin & 7 & JRV & Fast traveling \\
\hline 10-Jun-00 & Geopulse & $\mathrm{N}$ & 0306 & 0306 & 0308 & 6 & Bottlenose dolphin & 14 & JRV & Slow traveling \\
\hline 10-Jun-00 & Geopulse & $\mathrm{N}$ & 0440 & 0440 & 0446 & 1 & Risso's dolphin? & 15 & $\mathrm{ABD}$ & Slow traveling \\
\hline 10-Jun-00 & Geopulse & $\mathrm{D}$ & 1310 & 1315 & 1322 & 60 & Common dolphin & 21 & ABD & Milling then bowriding \\
\hline 10-Jun-00 & Geopulse & $\mathrm{D}$ & 1645 & 1645 & 1654 & 1 & California sea lion & 23 & TEC & Fast traveling, swam under boat \\
\hline 11-Jun-00 & Geop./Hunt. & $\mathrm{D}$ & 1524 & 1534 & 1600 & 50 & Common dolphin & 36 & TEC & Fast traveling \\
\hline 12-Jun-00 & Geopulse & $\mathrm{D}$ & 1515 & 1515 & 1530 & 1 & Blue whale & 49 & $\mathrm{ABD}$ & Slow traveling, outside zone \\
\hline 13-Jun-00 & Huntec & $\mathrm{D}$ & 1631 & 1632 & 1639 & 12 & Common dolphin & 54 & $\mathrm{ABD}$ & Bow riding \\
\hline 13-Jun-00 & Geopulse & $\mathrm{N}$ & 2240 & 2240 & 2252 & 30 & Common dolphin & 57 & LSB & Fast traveling \\
\hline 14-Jun-00 & Geopulse & $\mathrm{N}$ & 0034 & 0034 & 0129 & 12 & Common dolphin & 58 & DKE & Fast traveling \\
\hline 14-Jun-00 & Geopulse & $\mathrm{D}$ & 2003 & 2003 & 2009 & 30 & Common dolphin & 65 & TEC & Slow traveling then accelerated \\
\hline 15-Jun-00 & Huntec & $\mathrm{N}$ & 0500 & 0500 & 0506 & 12 & Common dolphin & 66 & LSB & Bow riding \\
\hline 15-Jun-00 & Geopulse & $\mathrm{D}$ & 0558 & 0558 & 0603 & 12 & Common dolphin & 71 & LSB & Bow riding \\
\hline 15-Jun-00 & Geopulse & $\mathrm{D}$ & 0631 & 0634 & 0636 & 75 & Common dolphin & 74 & ABD & $\begin{array}{l}\text { Fast traveling, part of group } \\
\text { approaches boat }\end{array}$ \\
\hline 15-Jun-00 & Huntec & $\mathrm{D}$ & 0912 & 0914 & 0917 & 28 & Common dolphin & 79 & $\mathrm{ABD}$ & Slow traveling \\
\hline 15-Jun-00 & Huntec & $\mathrm{D}$ & 1035 & 1036 & 1040 & 12 & Risso's dolphin & 81 & LSB & Slow traveling \\
\hline 15-Jun-00 & Geopulse & $\mathrm{N}$ & 2328 & 2328 & 2335 & 3 & Unidentified dolphin & 83 & DKE & Fast traveling \\
\hline 16-Jun-00 & Geopulse & $\mathrm{N}$ & 0025 & 0025 & 0032 & 5 & Common dolphin & 84 & TEC & Slow traveling \\
\hline 16-Jun-00 & Minisparker & $\mathrm{N}$ & 2152 & 2152 & 2159 & 1 & Common dolphin & 89 & JRV & Slow traveling \\
\hline 17-Jun-00 & Huntec & $\mathrm{D}$ & 2025 & 2025 & 2028 & 12 & Common dolphin & 94 & JRV & Fast traveling \\
\hline 17-Jun-00 & Huntec & $\mathrm{N}$ & 2118 & 2118 & 2121 & 2 & Common dolphin & 95 & JRV & Bow riding \\
\hline 17-Jun-00 & Huntec & $\mathrm{N}$ & 2146 & 2146 & 2155 & 40 & Common dolphin & 96 & JRV & Fast traveling \\
\hline 18-Jun-00 & Huntec & $\mathrm{N}$ & 0452 & 0452 & 0500 & 6 & Bottlenose dolphin? & 97 & DKE & Slow traveling \\
\hline 18-Jun-00 & Huntec & $\mathrm{D}$ & 0935 & 0936 & 0939 & 10 & Bottlenose and Risso's dolphin & 109B & LSB & Fast traveling \\
\hline 18-Jun-00 & Minisparker & $\mathrm{D}$ & 1929 & 1935 & 1954 & 20 & Common dolphin & 119 & $\mathrm{ABD}$ & Milling \\
\hline 19-Jun-00 & Huntec & $\mathrm{N}$ & 2234 & 2234 & 2239 & 2 & Common dolphin & 130 & TEC & Slow traveling \\
\hline 20-Jun-00 & Huntec & $\mathrm{D}$ & 0647 & 0650 & 0653 & 120 & Common dolphin & 134 & JRV & Fast traveling \\
\hline 20-Jun-00 & Huntec & $\mathrm{N}$ & 2331 & 2331 & 2335 & 1 & Common dolphin & 141 & TEC & Slow traveling \\
\hline 20-Jun-00 & Huntec & $\mathrm{N}$ & 2357 & 2357 & 0002 & 4 & Common dolphin & 142 & TEC/LSB & Slow traveling \\
\hline 21-Jun-00 & Huntec & $\mathrm{N}$ & 0014 & 0014 & 0019 & 3 & Common dolphin & 143 & JRV & Bow riding \\
\hline 23-Jun-00 & Huntec & $\mathrm{N}$ & 0121 & 0121 & 0123 & 2 & Bottlenose dolphin & 166 & JRV & Fast traveling \\
\hline 24-Jun-00 & Minisparker & D & 0613 & 0617 & 0650 & 1 & California sea lion & 184 & TEC & Slow traveling \\
\hline 25-Jun-00 & Huntec & $\mathrm{N}$ & 2303 & 2303 & 2308 & 3 & Common dolphin & 204 & JRV & Bow riding \\
\hline 27-Jun-00 & Huntec & $\mathrm{N}$ & 0456 & 0458 & 0503 & 20 & Common dolphin & 219 & JRV & Slow traveling \\
\hline 27-Jun-00 & Huntec & $D$ & 0605 & 0605 & 0606 & 1 & California sea lion & 222 & $\mathrm{ABD}$ & Slow traveling \\
\hline 27-Jun-00 & Huntec & $\mathrm{D}$ & 0956 & 0957 & 1016 & 18 & Common dolphin & 228 & TEC & $\begin{array}{l}\text { Slow traveling, testing equip } \\
\text { delayed restart }\end{array}$ \\
\hline 27-Jun-00 & Minisparker & $\mathrm{D}$ & 1124 & 1130 & 1134 & 60 & Common dolphin & 234 & DKE & Slow traveling \\
\hline 27-Jun-00 & Minisparker & $D$ & 1143 & 1147 & 1154 & 65 & Common dolphin & 235 & DKE & Fast traveling \\
\hline 27-Jun-00 & Huntec & $\mathrm{D}$ & 1159 & 1159 & 1205 & 65 & Common dolphin & 235 & DKE & Fast traveling \\
\hline 27-Jun-00 & Huntec & $\mathrm{D}$ & 1220 & 1220 & 1222 & 700 & Common dolphin & 239 & LSB & Fast traveling \\
\hline
\end{tabular}


Table 4. Percent of sightings resulting in shut-downs during sound transmissions.

\begin{tabular}{|l|l|l|l|}
\hline Species & Sightings & Shut-downs & $\%$ of sightings \\
\hline Pinnipeds & & & \\
\hline California sea lion & 69 & 3 & $4 \%$ \\
\hline Other pinniped & 3 & 0 & $0 \%$ \\
\hline All pinniped & 72 & 3 & $4 \%$ \\
\hline & & & \\
\hline Small cetaceans & & & \\
\hline Common dolphin & 68 & 29 & $43 \%$ \\
\hline Bottlenose dolphin & 10 & 4 & $40 \%$ \\
\hline Risso's dolphin & 13 & 3 & $23 \%$ \\
\hline Dall's porpoise & 2 & 0 & $0 \%$ \\
\hline Unident. dolphin & 30 & 1 & $3 \%$ \\
\hline All small cetaceans & 123 & 37 & $30 \%$ \\
\hline & & & \\
\hline Large cetaceans & & & \\
\hline Blue whale & 5 & $1^{*}$ & $20 \%{ }^{*}$ \\
\hline Other whales & 6 & 0 & $0 \%$ \\
\hline All large cetaceans & 11 & 1 & $9 \%$ \\
\hline
\end{tabular}

* Single large cetacean shut-down was precautionary (outside safety zone) 
Table 5. Summary of effort, sightings, and shut-downs by operational conditions and day/night.

\begin{tabular}{|c|c|c|c|c|c|c|c|}
\hline \multirow[t]{2}{*}{ Sound operation } & \multirow[t]{2}{*}{ Hours } & \multicolumn{2}{|c|}{ Large cetaceans } & \multicolumn{2}{|c|}{ Small cetaceans } & \multicolumn{2}{|c|}{ Pinnipeds } \\
\hline & & \# Sit & \# S/D & \# Sit & \# S/D & \# Sit & \# S/D \\
\hline \multicolumn{8}{|l|}{ Day } \\
\hline None & 47 & 1 & & 5 & & 18 & \\
\hline Geopulse & 102 & 4 & 1 & 26 & 4 & 21 & 1 \\
\hline Huntec & 94 & 6 & & 52 & 10 & 25 & 1 \\
\hline Sparker & 50 & 1 & & 12 & 3 & 27 & 1 \\
\hline Uniboom & 2 & & & & & 1 & \\
\hline Geopulse/Huntec & 3 & & & 5 & 1 & & \\
\hline Other & 4 & & & & & & \\
\hline All day operations & 302 & 12 & 1 & 100 & 18 & 92 & 3 \\
\hline \multicolumn{8}{|l|}{\begin{tabular}{|l|} 
Night \\
\end{tabular}} \\
\hline None & 13 & & & 2 & & & \\
\hline Geopulse & 64 & & & 7 & 6 & & \\
\hline Huntec & 69 & & & 21 & 11 & 2 & \\
\hline Sparker & 20 & & & 1 & 1 & 4 & \\
\hline Uniboom & 0 & & & & & & \\
\hline Geopulse/Huntec & 0 & & & & & & \\
\hline Other & 2 & & & & & & \\
\hline All night operations & 168 & 0 & 0 & 31 & 18 & 6 & 0 \\
\hline
\end{tabular}


Table 6. Summary of primary behavior of marine mammals sighted (not including resightings). Number in parenthesis indicates portion seen while no sound source was on.

\begin{tabular}{|c|c|c|c|c|c|c|c|c|c|c|}
\hline & \multicolumn{9}{|c|}{ Primary behavior } & \multirow[b]{2}{*}{ Total } \\
\hline Species & Breaching & $\begin{array}{c}\text { Fast } \\
\text { travel }\end{array}$ & $\begin{array}{c}\text { Slow } \\
\text { travel }\end{array}$ & Bowriding & Milling & Hauled & Stationary & Dead & Unknown & \\
\hline Blue whale & & & 5 & & & & & & 1 & 6 \\
\hline Fin whale & & & 1 & & & & & & & 1 \\
\hline Humpback whale & $1(1)$ & & & & & & & & & $1(1)$ \\
\hline Minke whale & 1 & & 1 & & & & & & & 2 \\
\hline Unid. large whale & & & & & & & & & 2 & 2 \\
\hline Common dolphin & & $35(5)$ & 24 & 6 & $9(1)$ & & & & & $74(6)$ \\
\hline Risso's dolphin & & 1 & 12 & & 1 & & & & & 14 \\
\hline Dall's porpoise & & 2 & & & & & & & & 2 \\
\hline Bottlenose dolphin & & 3 & 5 & & 2 & & & & & 10 \\
\hline Unid. dolphin & & 17 & 10 & & $4(1)$ & & & & & $31(1)$ \\
\hline California sea lion & & $8(2)$ & 27 & & $4(1)$ & $38(8)$ & $8(7)$ & 1 & 1 & $87(18)$ \\
\hline Elephant seal & & & & & & & 1 & & & 1 \\
\hline Harbor seal & & 1 & 3 & & & 1 & 2 & & & 7 \\
\hline Unid. pinniped & & 1 & 2 & & & & & & & 3 \\
\hline All species & $2(1)$ & $68(7)$ & 90 & 6 & $20(3)$ & $39(8)$ & $11(7)$ & 1 & 4 & $241(26)$ \\
\hline
\end{tabular}


Table 7. Summary of orientation of marine mammals by operational condition during initial sighting and resightings in 2000.

\begin{tabular}{|c|c|c|c|c|c|c|c|c|c|c|c|c|}
\hline \multirow[b]{2}{*}{ Orientation } & \multicolumn{2}{|c|}{ None } & \multicolumn{2}{|c|}{ Geopulse } & \multicolumn{2}{|c|}{ Huntec } & \multicolumn{2}{|c|}{ Sparker } & \multicolumn{2}{|c|}{ Other } & \multicolumn{2}{|c|}{ All } \\
\hline & \# Sit. & \# Res. & \# Sit. & \# Res. & \# Sit. & \# Res. & \# Sit. & \# Res. & \# Sit. & \# Res. & \# Sit. & \# Res. \\
\hline Away & 2 & 4 & 9 & 3 & 11 & 3 & 2 & & & & 24 & 10 \\
\hline Left & 4 & & 17 & 2 & 43 & 6 & 7 & 1 & 1 & & 72 & 9 \\
\hline Right & 6 & 1 & 18 & 2 & 28 & 9 & 5 & 1 & 1 & 1 & 58 & 14 \\
\hline Toward & 3 & 2 & 6 & & 17 & & 6 & & 1 & 1 & 33 & 3 \\
\hline $\begin{array}{l}\text { Variable or not } \\
\text { determ. }\end{array}$ & 11 & 4 & 8 & 1 & 7 & 2 & 25 & & 3 & & 54 & 7 \\
\hline Total & 26 & 11 & 58 & 8 & 106 & 20 & 45 & 2 & 6 & 2 & 241 & 43 \\
\hline \multicolumn{13}{|c|}{ As percent of sightings under that condition } \\
\hline Away & $8 \%$ & $36 \%$ & $16 \%$ & $38 \%$ & $10 \%$ & $15 \%$ & $4 \%$ & $0 \%$ & $0 \%$ & $0 \%$ & $10 \%$ & $23 \%$ \\
\hline Left & $15 \%$ & $0 \%$ & $29 \%$ & $25 \%$ & $41 \%$ & $30 \%$ & $16 \%$ & $50 \%$ & $17 \%$ & $0 \%$ & $30 \%$ & $21 \%$ \\
\hline Right & $23 \%$ & $9 \%$ & $31 \%$ & $25 \%$ & $26 \%$ & $45 \%$ & $11 \%$ & $50 \%$ & $17 \%$ & $50 \%$ & $24 \%$ & $33 \%$ \\
\hline Toward & $12 \%$ & $18 \%$ & $10 \%$ & $0 \%$ & $16 \%$ & $0 \%$ & $13 \%$ & $0 \%$ & $17 \%$ & $50 \%$ & $14 \%$ & $7 \%$ \\
\hline Variable or ND & $42 \%$ & $36 \%$ & $14 \%$ & $13 \%$ & $7 \%$ & $10 \%$ & $56 \%$ & $0 \%$ & $50 \%$ & $0 \%$ & $22 \%$ & $16 \%$ \\
\hline
\end{tabular}

